\title{
KARAKTERISTIK LIMBAH DOMESTIK DI LINGKUNGAN MESS KARYAWAN PERTAMBANGAN BATUBARA
}

\author{
Reno Fitriyanti \\ Dosen Program Studi Teknik Kimia Universitas PGRI Palembang \\ e-mail : renofitriyanti@ymail.com
}

\begin{abstract}
ABSTRAK
Limbah domestik di lingkungan mess karyawan pertambangan batubara berasal dari kegiatan laundry, kantin dan kamar mandi. Limbah domestik dapat mengakibatkan pencemaran badan air dan mnimbulkan bau. Langkah awal pengelolaan limbah domestik dapat dilakukan dengan mengetahui karakterisrik limbah yang dihasilkan. Tujuan penelitian ini adalah untuk mengetahui karakteristik limbah domestik di lingkungan mess karyawan pertambangan batubara.. Metode yang dilakukan dalam penelitian ini adalah dengan mengambil sampel limbah yang berasal dari kegiatan domestik (mess karyawan, laudry dan kantin). Selanjutnya dilakukan pengukuran sampel di laboratorium. Parameter yang diukur adalah BOD, COD, TSS, pH, minyak dan lemak serta amoniak. Data yang didapat dianalisis secara deskriptif dan dibandingkan dengan baku mutu limbah domestik. Hasil penelitian menunjukkan limbah domestik di lingkungan mess karyawan pertambangan batubara memiliki nilai TSS sebesar $2 \mathrm{mg} / \mathrm{l}$, kandungan minyak sebesar $2,8 \mathrm{mg} / \mathrm{l}$, BOD $43 \mathrm{mg} / \mathrm{l}$, COD 135,3 mg/l serta kandungan amoniak 25,41 mg/l serta nilai $\mathrm{pH} \mathrm{7,1.}$ Berdasarkan baku mutu yang ditetapkan dalam Peraturan Menteri Lingkungan Hidup dan Kehutanan Republik Indonesia Nomor P.68/Menlhk/Setjen/Kum //8/2016 tentang Baku Mutu Limbah Domestik, nilai TSS, kandungan minyak dan lemak memenuhi baku mutu yang ditetapkan, namun nilai parameter COD, BOD dan amoniak melebihi baku mutu yang ditetapkan.
\end{abstract}

Kata kunci : limbah domestik, BOD, COD, amoniak

\section{PENDAHULUAN}

Air merupakan materi yang essensial bagi kehidupan manusia, dimana ketersediaan air, semakin lama dirasakan semakin kritis, terutama akibat aktivitas kehidupan manusia itu sendiri. Limbah sebagian besar dihasilkan dari kegiatan manusia, dimana terus terjadi peningkatan dari segi kuantitas dan jenis limbah. Pembuangan limbah yang tidak melalui proses pengolahan merupakan salah satu masalah pencemaran lingkungan yang dihadapi (Sudirman dkk, 2015). Scortar (2009) menyatakan pengelolaan limbah yang tidak efektif dan efisien dapat merusak lingkungan dan mengganggu kesehatan.

Limbah cair merupakan buangan yang dihasilkan dari proses produksi dan domestik yang tidak dimanfaatkan serta dapat menimbulkan dampak bagi lingkungan. Pertambangan batubara, selain dihasilkan dari proses pertambangan, limbah juga dapat dihasilkan dari sektor domestik di lingkungan pertambangan. Limbah domestik tidak terkait pada proses produksi. Sumber limbah domestik di lingkungan pertambangan dihasilkan dari kegiatan karyawan berupa penggunaan kamar mandi, laundry dan kantin. Kandungan organik pada limbah domestik masih menjadi masalah penting yang mengakibatkan penurunan kualitas air sungai (Purwatiningrum, 2018). Data Kementrian Lingkungan 
Hidup tahun 2014 menunjukkan lebih dari 60\% sungai di Indonesia tercemar limbah domestik (Asadiya dan Nieke, 2018).

Penanganan Limbah yang efektif memerlukan informasi terkait karakteristik limbah yang dihasilkan. Pengetahuan terkait karakteristik limbah dapat menjadi hal utama dalam proses pengendalian dampak terhadap lingkungan sehingga hasil pengolahan limbah domestik memenuhi baku mutu limbah domestik.

Tujuan penelitian ini adalah untuk mengetahui karakteristik limbah domestik di lingkungan pertambangan batubara. Hasil pengukuran terhadap parameter limbah domestik selanjutnya dibandingkan dengan baku mutu limbah domestik sesuai dengan Peraturan Menteri Lingkungan Hidup dan Kehutanan Republik Indonesia Nomor P.68/Menlhk/Setjen/Kum I/8/2016 tentang Baku Mutu Limbah Domestik.

\section{TINJAUAN PUSTAKA}

Lingkungan merupakan kesatuan ruang dengan semua benda, daya, keadaan dan makhluk hidup. Arutanti (2009) mendefinisikan pencemaran lingkungan sebagai masuk atau dimasukkannya makhluk hidup, zat, energi dan atau komponen lainnya kedalam lingkungan sehingga kualitas lingkungan turun samapai ketinggat tertentu yang menyebabkan lingkungan menjadi kurang atau tidak dapat berfungsi lagi dengan peruntukannya.

Limbah cair merupakan hasil buangan yang dapat berupa bahan organik dan anorganik yang terlarut. Limbah cair mempunyai karakteristik fisika, kimia dan biologi. Karakteristik fisika antara lain suhu, bau, densitas, warna, Total Suspended Solid (TSS), Total Solid (TS), konduktivitas dan kekeruhan. Karakteristik kimia terdiri atas Biological Oxygen Demand (BOD), Chemical Ocygen Demand (COD), Protein, Karbohidrat, minyak dan lemak serta derajat keasaman (pH). Karakteritik biologi terdiri atas bakteri dan mikroorganisme (Metcalf dan Eddy, 2003).

Limbah domestik berasal dari kegiatan operasional domestik, dimana memiliki komponen utama berupa bahan organik dan detergent. Kandungan bahan organik didalam limbah cair biasanya berupa protein, karbohidrat serta minyak dan lemak (Kodoatie dan Syarief, 2010). Pembuangan limbah domestik dengan kandungan bahan organik yang disertai lemak dapat menjadi media bagi pertumbuhan mikroorganisme dan menyebabkan bau busuk akibat proses pembusukan.

Indikator bahwa perairan telah tercemar adalah adanya perubahan:

1. suhu

2. $\mathrm{pH}$

3. warna, rasa dan bau

4. timbulnya endapan, koloid, bahan terlarut

5. mikroorganisme

6. meningkatnya radioaktivitas air

Agar limbah yang dibuang tidak menyebabkan masalah lingkungan, diperlukan upaya penanganan pengelolaan limbah, dengan tujuan:

(1) Pencegahan polusi air permukaan

(2) Melindungibiota tanah dan perairan

(3) Pencegahan perkembangan bibit penyakit dan vektor

(4) Menjaga estetika lingkungan

Beberapa informasi yang dibutuhkan dalam menentukan unit pengolah limbah cair adalah (Kristanto, 2002):

(1) data kualitas dan kuantitas limbah cair,

(2) data penggunaan lahan, 
(3) data kondisi lingkungan badan air penerima, dan

(4) informasi peraturan pembuangan limbah cair

\section{METODELOGI PENELITIAN}

Penelitian ini dilakukan di lapangan dan laboratorium. Kegiatan di lapangan dilakukan dengan mengambil sampel limbah yang berasal dari kegiatan domestik (mess karyawan, laudry dan kantin). Selanjutnya dilakukan pengukuran sampel di laboratorium. Parameter yang diukur adalah BOD, COD, TSS, $\mathrm{pH}$, minyak dan lemak serta amoniak.

\section{Alat dan Bahan}

Peralatan dan bahan yang digunakan dalam penelitian ini meliputi botol DO, labu ukur, pipet, cawan aluminium, kaca arloji, penjepit, DOmeter, oven, desikator, timbangan analitik, pHmeter, kertas saring, picnometer, gelas, alat centrifugal, pompa vakum, ukur,corong, neraca analitik, $\mathrm{KH}_{2} \mathrm{PO}_{4}$, $\mathrm{K}_{2} \mathrm{HPO}_{4}, \mathrm{NH}_{4} \mathrm{Cl}, \mathrm{NaOH}, \mathrm{MgSO}_{4} .7 \mathrm{H}_{2} \mathrm{O}, \mathrm{CaCl}_{2}, \mathrm{FeCl}_{3} \cdot 6 \mathrm{H}_{2} \mathrm{O}$, suspensi bibit mikroba, $\mathrm{H}_{2} \mathrm{SO}_{4}, \mathrm{Na}_{2} \mathrm{SO}_{3}$, $\mathrm{CH}_{3} \mathrm{COOH}, \mathrm{KI}$, amilum, n-heksan, $\mathrm{MTBE}, \mathrm{Na}_{2} \mathrm{SO}_{4}$ dan aquadest.

\section{Prosedur Penelitian}

Sampel limbah domestik di lingkungan mess karyawan pertambangan batubara diambil secara sesaat dari kolam penampungan limbah cair. Limbar domestik selanjutnya dianalisa kandungan BOD, COD, TSS, $\mathrm{pH}$, minyak dan lemak serta amoniak.

\section{Analisis Data}

Data hasil pengukuran parameter adalah BOD, COD, TSS, pH, minyak dan lemak serta amoniak pada limbah domestik di lingkungan mess karyawan pertambangan batubara dibandingkan dengan baku mutu limbah domestik berdasarkan Peraturan Menteri Lingkungan Hidup dan Kehutanan Republik Indonesia Nomor P.68/Menlhk/Setjen/Kum I/8/2016 tentang Baku Mutu Limbah Domestik dan dianalisa secara deskriptif.

\section{HASIL DAN PEMBAHASAN}

Limbah domestik di lingkungan mess karyawan pertambangan batubara berasal dari kamar mandi, laudry dan dapur. Limbah yang dihasilkan sebanyak $15 \mathrm{~m}^{3} /$ hari. Hasil analisis limbah domestik pada kolam penampungan limbah domestik sebagai berikut (Tabel 1).

Tabel 1. Hasil Pengukuran Limbah Domestik

\begin{tabular}{|l|l|c|c|c|}
\hline \multicolumn{1}{|c|}{ No } & \multicolumn{1}{|c|}{ Parameter } & Satuan & Hasil Pengukuran & Baku Mutu* \\
\hline 1. & BOD & $\mathrm{mg} / \mathrm{l}$ & 43,0 & 30 \\
\hline 2. & COD & $\mathrm{mg} / \mathrm{l}$ & 135,3 & 100 \\
\hline 3. & TSS & $\mathrm{mg} / \mathrm{l}$ & 2 & 30 \\
\hline 4. & pH & - & 7,11 & \\
\hline 5. & Minyak dan Lemak & $\mathrm{mg} / \mathrm{l}$ & 2,8 & 5 \\
\hline 6. & Amoniak $\left(\mathrm{NH}_{3}\right)$ & $\mathrm{mg} / \mathrm{l}$ & 25,41 & 10 \\
\hline
\end{tabular}

*Peraturan Menteri Lingkungan Hidup dan Kehutanan Republik Indonesia Nomor P.68/Menlhk/Setjen/Kum I/8/2016 tentang Baku Mutu Limbah Domestik 


\section{Kebutuhan Oksigen Biologi (BOD)}

Banyaknya oksigen yang dibutuhkan mikroorganisme untuk menguraikan bahan organik di perairan dikenal dengan Biological Oxygen Demand (BOD). Tingginya nilai BOD merupakan salah satu indikator yang menunjukkan banyaknya beban pencemaran yang bersumber dari zat organik terlarut yang terdapat di perairan tersebut (Aswir, 2006). Hasil pengukuran BOD pada limbah domestik dari lingkungan mess karyawan pertambangan batubara menunjukkan nilai $43 \mathrm{mg} / \mathrm{l}$. Nilai ini berada melebihi /diatas nilai baku mutu yang ditetapkan dalam Peraturan Menteri Lingkungan Hidup dan Kehutanan Republik Indonesia Nomor P.68/Menlhk/Setjen/ Kum I/8/2016 tentang Baku Mutu Limbah Domestik yaitu sebesar $30 \mathrm{mg} / \mathrm{l}$

\section{Kebutuhan Kandungan Kimia (COD)}

Chemical Oxygen Demand (COD) merupakan ukuran kebutuhan oksigen yang digunakan oksidator untuk proses oksidasi semua zat organik dan anorganik melalui reaksi kimia di dalam perairan. Hasil pengukuran COD pada limbah domestik dari lingkungan mess karyawan pertambangan batubara menunjukkan nilai $135,3 \mathrm{mg} / \mathrm{l}$. Nilai ini melebihi/ diatas nilai baku mutu yang ditetapkan dalam Peraturan Menteri Lingkungan Hidup dan Kehutanan Republik Indonesia Nomor P.68/Menlhk/Setjen/Kum I/8/2016 tentang Baku Mutu Limbah Domestik yaitu sebesar $100 \mathrm{mg} / \mathrm{l}$. Sugito (2008) menyatakan tingginya kandungan COD dapat diakibatkan adanya kandungan di dalam air limbah yang tidak dapat diuraikan oleh mikroorganisme.

\section{Padatan Tersuspensi (TSS)}

TSS merupakan total suspenden solid atau padatan tersuspensi yang menyatakan kandungan bahan tersuspensi di dalam limbah. TSS menunjukkan banyaknya bahan tersuspensi seperti pasir, jasad renik, lumpur (Effendi ,2003) yang tertahan oleh saringan berdiameter 0,45 $\mu \mathrm{m}$. Kandungan TSS yang tinggi berpengaruh terhadap proses fotosintesis dengan menghalangi sinar matahari masuk ke perairan dan berdampak pada biota perairan. Bahan tersuspensi dapat juga berasal dari limbah organik yang jika terjadi degradasi pada bahan organik tersebut dapat mengakitkan kandungan oksigen di perairan menurun. Hasil pengukuran TSS pada limbah domestik dari lingkungan mess karyawan pertambangan batubara menunjukkan nilai $2 \mathrm{mg} / \mathrm{l}$. Nilai ini memenuhi baku mutu dan berada jauh dibawah nilai baku mutu yang ditetapkan dalam Peraturan Menteri Lingkungan Hidup dan Kehutanan Republik Indonesia Nomor P.68/Menlhk/Setjen/Kum I/8/2016 tentang Baku Mutu Limbah Domestik yaitu sebesar $30 \mathrm{mg} / \mathrm{l}$.

\section{Derajat keasaman $(\mathbf{p H})$}

Produktivitas perairan merupakan gambaran produktivitas organisme yang terdapat didalamnya. Produktivitas tersebut dipengaruhi oleh kelarutan zat/mineral di perairan, dimana, derajat keasaman merupakan salah satu parameter penting yang mempengaruhi kelarutan zat/mineral tersebut. Perairan dengan $\mathrm{pH}$ antara 6-8 memiliki produktivitas yang baik, sebaliknya $\mathrm{pH}$ yang berada diluar batas normal tersebut dapat mengganggu kehitupan biota perairan (Effendi, 203). Hasil pengukuran pH limbah domestik dari lingkungan mess karyawan pertambangan batubara menunjukkan nilai derajat keasaman netral yaitu 7,11 .

\section{Minyak dan Lemak}

Minyak dan lemak merupakan komponen yang sulit untuk diuraikan oleh mikroba dan merupakan komponen utama bahan makanan yang terdapat didalam limbah cair. Ganefati (2011) menyatakan kekurangan oksigen di perairan dapat menyebakan kematian biota air, dimana salah satu penyebabnya adalah tertutupnya permukaan air oleh minyak sehingga menghalangi masuknya oksigen. Hasil 
pengukuran kandungan minyak dan lemak pada limbah domestik dari lingkungan mess karyawan pertambangan batubara menunjukkan nilai $2,8 \mathrm{mg} / \mathrm{l}$. Nilai ini masih memenuhi nilai baku mutu yang ditetapkan dalam Peraturan Menteri Lingkungan Hidup dan Kehutanan Republik Indonesia Nomor P.68/Menlhk/Setjen/Kum I/8/2016 tentang Baku Mutu Limbah Domestik yaitu sebesar 5 mg/l.

\section{Amoniak}

Hasil pengukuran amoniak pada limbah domestik dari lingkungan mess karyawan pertambangan batubara menunjukkan nilai $25,41 \mathrm{mg} / \mathrm{l}$. Nilai kandungan amoniak ini melebihi baku mutu yang ditetapkan dalam Peraturan Menteri Lingkungan Hidup dan Kehutanan Republik Indonesia Nomor P.68/Menlhk/Setjen/Kum I/8/2016 tentang Baku Mutu Limbah Domestik yaitu sebesar 10 mg/l. Kandungan amoniak yang tinggi ini, berasal dari pembusukan protein dan merupakan salah satu indikasi terjadinya pencemaran. Sumber protein yang tinggi dapat berasal dari kantin yang menghasilkan bahan buangan yang memiliki kandungan protein.

\section{KESIMPULAN}

Limbah domestik yang berasal dari lingkungan mess karyawan pertambangan batubara memiliki nilai TSS sebesar $2 \mathrm{mg} / \mathrm{l}$ dan kandungan minyak sebesar $2,8 \mathrm{mg} / \mathrm{l}$ serta memenuhi baku mutu. Sementara itu, nilai BOD limbah sebesar $43 \mathrm{mg} / \mathrm{l}$ dan COD 135,3 mg/l serta kandungan amoniak 25,41 mg/l berada diatas/melebihi baku mutu yang ditetapkan dalam Peraturan Menteri Lingkungan Hidup dan Kehutanan Republik Indonesia Nomor P.68/Menlhk/Setjen/Kum I/8/2016 tentang Baku Mutu Limbah Domestik.

\section{DAFTAR PUSTAKA}

Arutanti, A.M., 2009. Penjernihan Air dari Pencemar Organik dengan Proses Fotokatalisis pada Permukaan Titanium Dioksida. Jurnal Nanosains Amp Nanoteknologi.

Asadiya, A., Nieke, N., 2018. Pengolahan Air Limbah Domestik Menggunakan Proses Aerasi, Pengendapan, dan Filtrasi Media Zeolite-Arang Aktif. Jurnal Teknik ITS Vol 7 No. 1

Aswir. 2006. Analisis Pencemaran Air Sungai Tapung Kiri oleh Limbah Industri Kelapa Sawit PT Peputra Masterindo di Kabupaten Sampar. Tesis. Universitas Diponegoro.

Effendi, H. 2003. Telaah Kualitas Air. Penerbit Kanisius. Yogyakarta

Ganefati Sri. 2011. Pengaruh Perasan Blimbing Wuluh terhadap Penurunan Kadar Lemak dan Angka Kuman dalam Pengolahan Limbah Cair Dapur. Poltekes Kemenkes. Yogyakarta.

Kodoatie R, Syarief R. 2010. Tata Ruang Air. Andi Offset. Yogyakarta.

Kristanto, P. 2004. Ekologi Industri. Andi Offset. Yogyakarta

Metcalf dan Eddy. 2003. Wastewater Engineering: Treatment, Disposal and Reuse. McGraw-Hill. USA

Purwatiningrum, O. 2018. Gambaran Instalasi Pengolahan Air Limbah Domestik Komunal Di Kelurahan Simokerto Kecamatan Simokerto Kota Surabaya. Jurnal Kesehatan Lingkungan Volume 10 No 2. P 243-253

Scortar, L.M. 2009. Household Waste Management around the Globe, Managerial Chalanges of the Contemporary Society. Proceedings: 249-256. Cluj-Napoca: Babes Bolyai University 
Sudirman, Andi R, Jasrudin, Sintesis dan Karakterisasi Nanopartikel Fotokatalis TiO2/Karbon Aktif Sebagai Adsorben Limbah Organik. 2015. Prosiding Pertemuan Ilmiah XXIX HFI Jateng \& DIY. ISSN 0853-0823

Sugito. 2008. Aplikasi Instalasi Pengolahan Air Limbah Biofilter untuk Menurunkan Kandungan Pencemar BOD, COD dan TSS di Rumah Sakit Bunda Surabaya. Prosiding Seminar Nasional

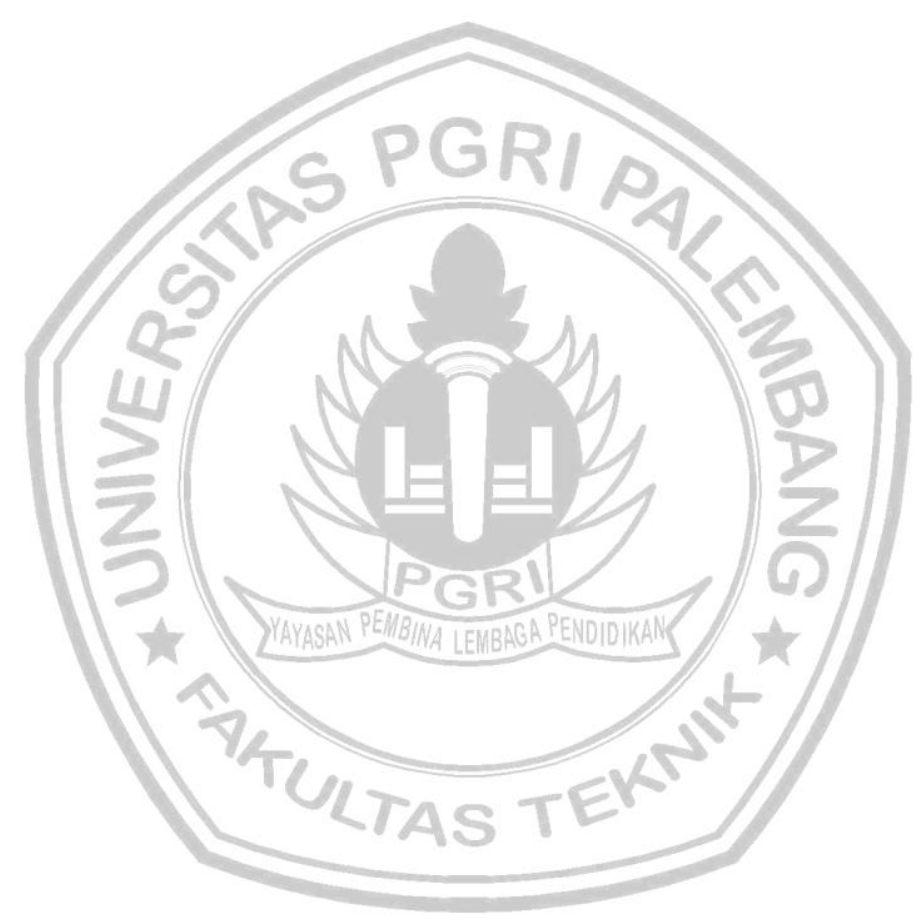

